\title{
Environment-friendly, flame retardant thermoplastic elastomer-magnesium hydroxide composites
}

\author{
Hao Tang*, ${ }^{*}$, Kunfeng Chen ${ }^{\star}$, Xiaonan $\mathrm{Li}^{\S}$, Man Ao", Xinwen Guo*, \\ and Dongfeng Xue*,**** \\ *School of Chemical Engineering, Dalian University of Technology \\ Dalian 116024, P. R. China \\ †Shenyang Fire Research Institute, Shenyang 110034, P. R. China \\ *State Key Laboratory of Rare Earth Resource Utilization \\ Changchun Institute of Applied Chemistry, Chinese Academy of Science \\ Changchun 130022, P. R. China \\ $\S_{\text {Sunrise Power Co., Ltd., Dalian 116085, P. R. China }}$ \\ IShenyang Gas Group Co., Ltd., Shenyang 110005, P. R. China \\ "lguoxw@dlut.edu.cn \\ **dongfeng@ciac.ac.cn
}

Received 12 May 2017; Accepted; 17 May 2017; Published 16 June 2017

\begin{abstract}
Halogen-free and environment-friendly magnesium hydroxide $\left(\mathrm{Mg}(\mathrm{OH})_{2}\right)$ was synthesized to enhance the flame retardant properties of thermoplastic elastomer (TPE). When the $\mathrm{Mg}(\mathrm{OH})_{2}$ content was optimized to $35 \mathrm{wt} . \%$, the TPE- $\mathrm{Mg}(\mathrm{OH})_{2}$ composites exhibited the best flame retardant properties. The results showed that there was a delay of ignition time of the samples containing $\mathrm{Mg}(\mathrm{OH})_{2}$; compared with the samples without $\mathrm{Mg}(\mathrm{OH})_{2}$, the heat release rate and total heat release decrease by $31.4 \%$ and $35.6 \%$, while total smoke production and mass loss rate reduce by $56 \%$ and $34.2 \%$, respectively. This work opens a door to manufacture fire-resistant polymer-based composites with environmental-friendly flame retardant additives by controllable crystallization and chemical strategies.
\end{abstract}

Keywords: Thermoplastic elastomer; magnesium hydroxide; magnesium oxide; flame retardant performance.

As one kind of polymer material, thermoplastic elastomer (TPE) is widely used in automotive, home appliances, building seals, sports equipment and other industries. ${ }^{1}$ As polymer materials are very sensitive to flame, they will generate a large amount of heat, smoke, toxic gases in the combustion process, causing a fire hazard. ${ }^{2,3}$ Their flame retardant performance becomes a constraint for their wider application. Though the halogen and phosphorus have been used as a polymer flame retardant at the early stage, the problem of cost and environmental unfriendly limits their application. ${ }^{4,5}$ Therefore, various halogen-/phosphorus-free polymer flame retardant additives have been used to solve the above problems, for example, mineral fillers, and melamine compounds. ${ }^{6}$ Magnesium hydroxide $\left(\mathrm{Mg}(\mathrm{OH})_{2}\right)$, aluminum trihydroxide, and calcium carbonate are often used mineral fillers, which can occur as an endothermic decomposition reaction, absorb heat from the surrounding polymer material, and release water vapor/carbon dioxide, inhabit the polymer from oxygen and increase the heat capacity of the polymer without releasing any toxins. ${ }^{7,8}$ Among these mineral fillers, $\operatorname{Mg}(\mathrm{OH})_{2}$ has a higher decomposition temperature $\left(>340^{\circ} \mathrm{C}\right)$, higher heat absorbance capacity, higher decomposition enthalpy of $1.36 \mathrm{~kJ} / \mathrm{g}$, and lower smoke emission and nontoxicity, which is a hot environmentally friendly inorganic fire retardant. ${ }^{9,10}$ However, some disadvantages have restricted their application, i.e. (1) $\mathrm{Mg}(\mathrm{OH})_{2}$ has a hydrophilic surface, leading to particle aggregation and, (2) the $\mathrm{Mg}(\mathrm{OH})_{2}$ loading must be high

\footnotetext{
*** Corresponding author.

This is an Open Access article published by World Scientific Publishing Company. It is distributed under the terms of the Creative Commons Attribution 4.0 (CC-BY) License. Further distribution of this work is permitted, provided the original work is properly cited.
} 
(typically $>60 \mathrm{wt} . \%$ ) to achieve acceptable flame retardancy, decreasing the polymer mechanical properties. ${ }^{11,12}$

Recently, it is reported that the crystal size and morphology of $\mathrm{Mg}(\mathrm{OH})_{2}$ can affect its flame retardant effect and mechanical properties. $\mathrm{Mg}(\mathrm{OH})_{2}$ nanomaterial has a huge surface area, a high endothermic decomposition temperature, smoke suppressibility and better flame retardant properties compared to bulk $\mathrm{Mg}(\mathrm{OH})_{2} \cdot{ }^{13,14} \mathrm{Mg}(\mathrm{OH})_{2}$ crystals with flower-, sphere-, needle-, lamellar-, wire-, and rod-like morphologies, have been synthesized via different synthesis methods. ${ }^{15-19}$ Especially, the lamellar-like $\mathrm{Mg}(\mathrm{OH})_{2}$ with unique structure, mechanical and dispersing properties has been a good candidate for halogen-free flame retardant. Crystallization and chemical strategies would be a useful route to control the $\operatorname{Mg}(\mathrm{OH})_{2}$ crystal behaviors for the

Table 1. Mass ratio of $\mathrm{Mg}(\mathrm{OH})_{2}$ in TPE- $\mathrm{Mg}(\mathrm{OH})_{2}$ composites.

\begin{tabular}{llc}
\hline Sample & \multicolumn{1}{c}{ Components } & Ratio of $\mathrm{Mg}(\mathrm{OH})_{2}$ (wt.\%) \\
\hline I & $\mathrm{TPE}$ & 0 \\
II & $\mathrm{Mg}(\mathrm{OH})_{2}$ and TPE & 20 \\
III & $\mathrm{Mg}(\mathrm{OH})_{2}$ and TPE & 35 \\
\hline
\end{tabular}

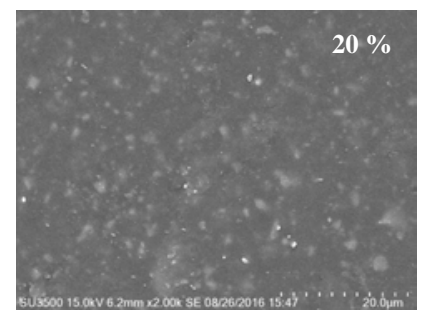

(a1)

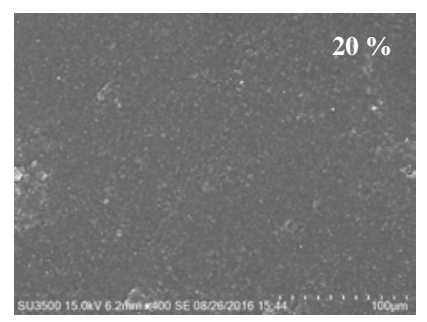

(a2)

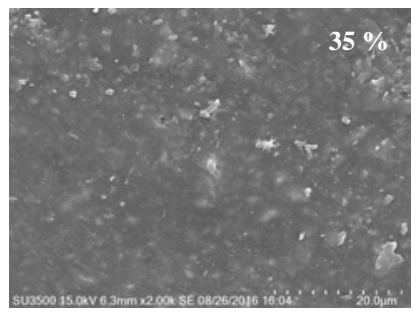

(b1)

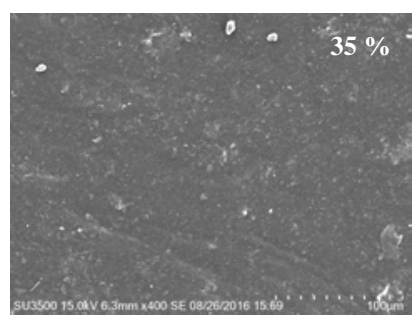

(b2)
Fig. 1. SEM images of TPE- $\mathrm{Mg}(\mathrm{OH})_{2}$ composites with different $\mathrm{Mg}(\mathrm{OH})_{2}$ loading: (a1,a2) $20 \mathrm{wt} . \%$, (b1,b2) $35 \mathrm{wt} . \%$. enhanced flame retardant properties. ${ }^{20-23}$ Herein, TPE-Mg $(\mathrm{OH})_{2}$ composites were prepared via double screw method, and different contents of $\mathrm{Mg}(\mathrm{OH})_{2}$ were added as flame retardant to demonstrate the effect of $\mathrm{Mg}(\mathrm{OH})_{2}$ as high filling flame retardants to TPE.

Typically, 1 equivalent $\mathrm{MgCl}_{2}$ and 2 equivalent $\mathrm{NaOH}$ were mixed in water solution by stirring. After reaction for $3 \mathrm{~h}$, the precipitates were filtered, and the samples were dried at $60^{\circ} \mathrm{C}$ for further use. The as-obtained $\mathrm{Mg}(\mathrm{OH})_{2}$ sample displayed lamellar-like shape. $100 \mathrm{~mm} \times 100 \mathrm{~mm} \times 8 \mathrm{~mm}$ flat flame retardant samples were prepared by mixing the TPE (TPE, Label: sp-jc680 nc001) with different contents of $\mathrm{Mg}(\mathrm{OH})_{2}$. The mass ratio of $\mathrm{Mg}(\mathrm{OH})_{2}$ added in the TPE-Mg $(\mathrm{OH})_{2}$ composites is shown in Table 1.

Usually above $60 \mathrm{wt} . \%$ of $\mathrm{Mg}(\mathrm{OH})_{2}$ was used in many cases to achieve effective flame retardant properties. However, high loading of $\mathrm{Mg}(\mathrm{OH})_{2}$ often resulted in nonuniform dispersion and interface issues. In this work, to maintain the mechanical properties of the TPE composites, the highest loading of $\mathrm{Mg}(\mathrm{OH})_{2}$ was kept at $35 \mathrm{wt} . \%$. The relatively smooth surface was found in TPE- $\mathrm{Mg}(\mathrm{OH})_{2}$ composites with 20 wt. $\%$ and 35 wt. $\%$ of $\mathrm{Mg}(\mathrm{OH})_{2}$ (Fig. 1). However, some $\mathrm{Mg}(\mathrm{OH})_{2}$ was bonded together to form agglomerates (white dot) in TPE composites. When the content of $\mathrm{Mg}(\mathrm{OH})_{2}$ increases from $20 \mathrm{wt} . \%$ to $35 \mathrm{wt} . \%$, the concentration of agglomerates was also increased. In the loading of $20 \mathrm{wt} . \%$ to $35 \mathrm{wt} . \%$, the mechanical properties of TPE- $\mathrm{Mg}(\mathrm{OH})_{2}$ composites were not fatefully declined.

Ignition time is one of the important indexes of combustion risk. As shown in Table 2, the ignition times of samples I-III are 60, 93 and $124 \mathrm{~s}$, respectively. The flame retardant mechanism of $\mathrm{Mg}(\mathrm{OH})_{2}$ can be shown as the following equation ${ }^{4}$ :

$$
\mathrm{Mg}(\mathrm{OH})_{2} \rightarrow \mathrm{MgO}+\mathrm{H}_{2} \mathrm{O} .
$$

After ignition, $\mathrm{Mg}(\mathrm{OH})_{2}$ is decomposed into $\mathrm{MgO}$ and $\mathrm{H}_{2} \mathrm{O}$, where the $\mathrm{MgO}$ isolate oxygen from polymer and $\mathrm{H}_{2} \mathrm{O}$ reduce combustible gas concentration, as well as the reaction adsorbs the released thermal energy. Therefore, it can be seen that the $\mathrm{Mg}(\mathrm{OH})_{2}$ delayed the ignition time of the polymer material, and the ignition time increases as the $\mathrm{Mg}(\mathrm{OH})_{2}$ content increases.

Heat release rate (HRR) is the key parameter to evaluate the flame retardant performance of the polymer material. As

Table 2. Burning behavior of TPE samples with adding different ratios of $\mathrm{Mg}(\mathrm{OH})_{2}$.

\begin{tabular}{lccccc}
\hline Sample & $t_{i g}(\mathrm{~s})$ & $\mathrm{HRR}_{\text {peak }}\left(\mathrm{kW} / \mathrm{m}^{2}\right)$ & $\mathrm{THR}_{600 \mathrm{~s}}\left(\mathrm{MJ} / \mathrm{m}^{2}\right)$ & $\mathrm{TSP}_{600 \mathrm{~s}}\left(\mathrm{~m}^{2}\right)$ & $\mathrm{MLR}_{\text {peak }}(\mathrm{g} / \mathrm{s})$ \\
\hline I & 60 & 269.02 & 100.33 & 10.41 & 0.038 \\
II & 93 & 208.21 & 95.77 & 8.78 & 0.028 \\
III & 124 & 184.59 & 64.60 & 4.58 & 0.025 \\
\hline
\end{tabular}


shown in Table 2, the $\mathrm{HRR}_{\text {peak }}$ of sample I was $269.02 \mathrm{~kW} /$ $\mathrm{m}^{2}$ and the $\mathrm{HRR}_{\text {peak }}$ of samples II and III was reduced by $22.6 \%$ and $31.4 \%$ compared with TPE sample I, respectively. The addition of $\operatorname{Mg}(\mathrm{OH})_{2}$ reduced the $\mathrm{HRR}_{\text {peak }}$ of the samples. The higher content of $\mathrm{Mg}(\mathrm{OH})_{2}$ represented the better flame retardance and heat suppression. According to Eq. (1), as-produced vaporos water in $\mathrm{Mg}(\mathrm{OH})_{2}$ thermal decomposition can attenuate flammable gas and the formed $\mathrm{MgO}$ heat insulation layer on the surface of flame prevents the flammable gas flowing.

Figure 2 shows the combustion process of samples I, II and III from the initial combustion to the sufficient combustion spent char. According to its dynamic process of dehydration and the thermal conductivity of the combustion residue, the flame retardant mechanism of $\mathrm{Mg}(\mathrm{OH})_{2}$ in the polymer can be achieved. With the $\operatorname{Mg}(\mathrm{OH})_{2}$ content increase, the amount of water release produced by flame retardant decomposition increases, which can dilute the flammable gas around the polymer. ${ }^{24}$ As shown in Fig. 2(a), sample I (115 s) entered sufficient combustion process before the samples II (120s) and III (175s), and time needed to sufficient combustion process extended with the content increase of $\mathrm{Mg}(\mathrm{OH})_{2}$. It indicates that the water released in the initial combustion of the samples plays a good suppressive effect on combustion. After first HRR peak, they entered the sufficient combustion process. The curves of the samples I and II gradually came close to each other, which were higher than that of sample III. After entering the sufficient combustion process, the obstruction of the flame mainly relied on the $\mathrm{MgO}$ layer, which had a combustion suppressive effect. The sample III has a higher content of $\mathrm{Mg}(\mathrm{OH})_{2}$, producing thick $\mathrm{MgO}$ layer, so that its flame retardant effect was the best.

The $600 \mathrm{~s}$ total heat release $\left(\mathrm{THR}_{600 \mathrm{~s}}\right)$ of sample I in Table 2 was $100.33 \mathrm{MJ} / \mathrm{m}^{2}$, and that of the samples II and III decreased by $4.5 \%$ and $35.6 \%$, respectively. As shown in Fig. 2(b), the start times of rapid increase of THR of the samples I, II and III were consistent with the ignition time. The time of sample III entering the sufficient combustion process was the latest, which is consistent with the curve characteristics of sample III in Fig. 2(a). The later it enters the

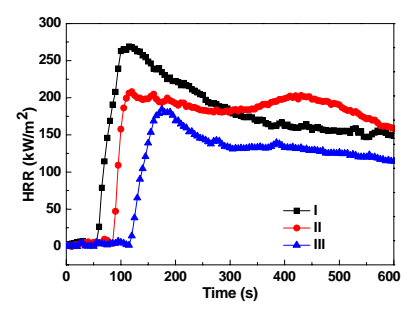

(a)

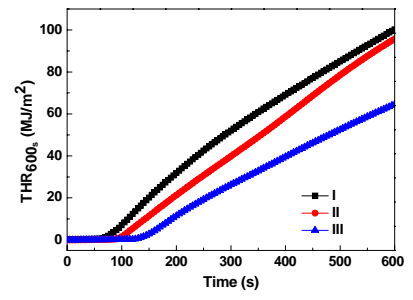

(b)
Fig. 2. (a) HRR curves and (b) THR curves of TPE- $\mathrm{Mg}(\mathrm{OH})_{2}$ composites. sufficient combustion process, the later the actual fire will be formed, and the greater the chance of taking emergency, evacuating and escaping measures will be possible. Therefore, the increase of the $\mathrm{Mg}(\mathrm{OH})_{2}$ content is an effective measure to enhance the fire retardance of TPE.

The curve of sample II gradually came close to sample I over combustion time, and the curve of sample III remained constant (Fig. 2(b)). It indicates that the sample with 20wt.\% $\mathrm{Mg}(\mathrm{OH})_{2}$ did not produce an obvious flame retardant effect during the complete combustion stage. When the $\mathrm{Mg}(\mathrm{OH})_{2}$ content was increased to $35 \mathrm{wt} . \%$, it could effectively inhibit the heat release in the combustion. The experiment also confirmed that delamination or shedding did not occur to the samples in the combustion process, which proved that $\mathrm{Mg}(\mathrm{OH})_{2}$ in TPE had good compatibility when the content did not exceed $35 \mathrm{wt} . \%$.

The initial stage of fire is the best time for evacuation and escape, and a large amount of toxic smoke is the major cause of fire casualties. Therefore, the total smoke production of materials in the initial combustion is also an important indicator of the flame retardant performance of materials. As shown in Table 2, the $600 \mathrm{~s}$ total smoke production $\left(\mathrm{TSP}_{600 \mathrm{~s}}\right.$ ) of the samples reflects the amount of smoke and particles produced during the combustion. The $\mathrm{TSP}_{600 \mathrm{~s}}$ of the samples II and III were $15.6 \%$ and 56\% lower than that of sample I $\left(10.41 \mathrm{~m}^{2}\right)$. The addition of $\mathrm{Mg}(\mathrm{OH})_{2}$ reduced the amount of smoke production.

Seen from Fig. 3(a), the start time of sample III producing large amount of smoke was significantly later than that of other samples. In the initial combustion stage, $\mathrm{Mg}(\mathrm{OH})_{2}$ can inhibit the smoke production. $\mathrm{Mg}(\mathrm{OH})_{2}$ has good thermal stability, and decomposes in the temperature range of 340 $490^{\circ} \mathrm{C}$. The flame retardant of $\mathrm{Mg}(\mathrm{OH})_{2}$ mainly occurs at temperature range of solid phase decomposition, which reduces the production of combustible gas and then leads to less smoke volume. This smoke-inhibiting effect was significant in the initial combustion, but very limited in the sufficient combustion process.

After entering the sufficient combustion process, $\mathrm{Mg}$ $(\mathrm{OH})_{2}$ decomposed to form $\mathrm{MgO}$, which contributed to the

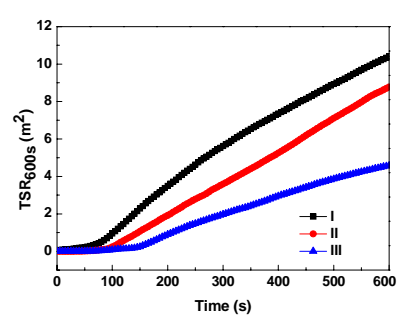

(a)

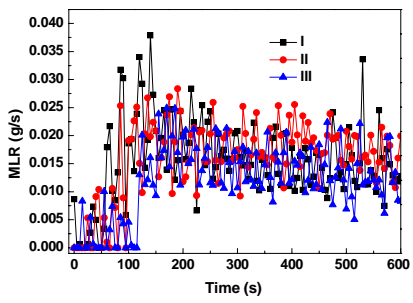

(b)
Fig. 3. (a) TSP and (b) MLR curves of TPE- $\mathrm{Mg}(\mathrm{OH})_{2}$ composites. 
formation of the charring layer on the surface..$^{25}$ The charring layer was dense and heat resistant, and could suppress the smoke production effectively throughout the combustion process. This is also the reason that inorganic flame retardants as environmental friendly flame retardant are superior to the other flame retardants. The smoke-inhibiting effect was not obvious at $20 \mathrm{wt} . \% \mathrm{Mg}(\mathrm{OH})_{2}$. The smoke-inhibiting effect of sample III was significantly better than that of sample II, indicating that the increase of $\mathrm{Mg}(\mathrm{OH})_{2}$ content could effectively reduce smoke production.

The mass loss rate $\left(\mathrm{MLR}_{\text {peak }}\right)$ of sample I was $0.038 \mathrm{~g} / \mathrm{s}$, and that of the samples II and III were decreased by $26.3 \%$ and $34.2 \%$, respectively (Table 2). MLR peak $_{\text {of sample I was }}$ significantly higher than that of the other samples (Fig. 3(b)). The MLR of sample III was lower than that of samples II and III. After achieving the $\mathrm{MLR}_{\text {peak }}$ at $140 \mathrm{~s}$, high MLR peaks continued to appear in sample I, while the samples II and III were relatively stable after achieving the $\mathrm{MLR}_{\text {peak }}$ at $200 \mathrm{~s}$. The decomposition temperature range of $\mathrm{Mg}(\mathrm{OH})_{2}$ with high decomposition rate is at $430^{\circ} \mathrm{C}$ to $490^{\circ} \mathrm{C}$, and the heat absorption during the decomposition was about $44.8 \mathrm{~kJ} / \mathrm{mol}$. Not only did the heat absorption reduce the generation of combustibles during the decomposition process, but also the oxide layer formed after the decomposition had a thermal insulation effect, so that $\mathrm{Mg}(\mathrm{OH})_{2}$ can significantly reduce the MLR of the samples in the sufficient combustion process. The increased $\mathrm{Mg}(\mathrm{OH})_{2}$ content produced better suppressive effect on the burning rate.

In summary, the combustion properties of TPE samples with adding different loading of $\mathrm{Mg}(\mathrm{OH})_{2}$ as flame retardant were studied. The results showed that there was a delay of ignition time of the samples containing $\mathrm{Mg}(\mathrm{OH})_{2}$; compared with the samples without $\mathrm{Mg}(\mathrm{OH})_{2}$, the $\mathrm{HRR}_{\text {peak }}$ of those samples containing $20 \mathrm{wt} . \%$ and $35 \mathrm{wt} . \% \mathrm{Mg}(\mathrm{OH})_{2}$ decrease by $22.6 \%$ and $31.4 \%$, the $\mathrm{THR}_{600 \mathrm{~s}}$ reduces by $4.5 \%$ and $35.6 \%$, while the $\mathrm{TSP}_{600 \mathrm{~s}}$ decreases by $15.6 \%$ and $56 \%$, respectively. The smoke-inhibiting effect of the sample containing $35 \mathrm{wt} . \% \mathrm{Mg}(\mathrm{OH})_{2}$ was significantly better than that of the $20 \mathrm{wt} . \% \mathrm{Mg}(\mathrm{OH})_{2}$ sample, indicating that the increase of $\mathrm{Mg}(\mathrm{OH})_{2}$ content could effectively increase the flame retardant performance of TPE. The increased $\mathrm{Mg}(\mathrm{OH})_{2}$ loading in TPE produced better suppressive effect on the burning rate, ignition time and smoke production.

\section{Acknowledgment}

Financial support from the National Natural Science Foundation of China (Grant Nos. 51125009 and 91434118) is acknowledged.

\section{References}

1. K. Q. Shen, Unsaturated Polyester Resin and its Applications (Chemical industry press, Beijing, 1988).

2. H. A. Lecomte and J. J. Liggat, Polym. Degrad. Stab. 93, 498 (2008).

3. Y. Yang, M. Niu, J. Li, B. Xue and J. Dai, Polym. Degrad. Stab. 134, 1 (2016).

4. H. Lu, W. Yang, S. Zhou, W. Xing, L. Song and Y. Hu, Polym. Adv. Technol. 21, 113 (2010).

5. M. Yousefi, E. Noori, D. Ghanbari, M. Salavati-Niasari and T. Gholami, J. Cluster Sci. 25, 397 (2014).

6. L. Haurie, A. I. Fernandez, J. I. Velasco, J. M. Chimenos, J. M. L. Cuesta and F. Espiell, Polym. Degrad. Stab. 91, 989 (2006).

7. J. Noh, I. Kang, J. Choi, H. Fatima, P. J. Yoo, K. W. Oh and J. Park, Polym. Bull. 73, 2855 (2016).

8. J. Liu and Y. Zhang, Polym. Degrad. Stab. 96, 2215 (2011).

9. P. R. Hornsby and C. L. Watson, Polym. Degrad. Stab. 30, 73 (1990).

10. H. D. Lu, Y. Hu, L. Yang, Z. Z. Wang, Z. Y. Chen and W. C. Fan, Macromol. Mater. Eng. 289, 984 (2004).

11. J. Z. Liang, Y. J. Zhang and X. H. Jian, Polym. Bull. 66, 289 (2011).

12. M. Wang, X. Han, L. Liu, X. Zeng, H. Zou, J. Wang and J. Chen, Ind. Eng. Chem. Res. 54, 12805 (2015).

13. M. A. Alavi and A. Morsali, Ultrason. Sonochem. 17, 441 (2010).

14. J. Zhao, X. Zhang, R. Tu, C. Lu, X. He and W. Zhang, Cellulose 21, 1859 (2014).

15. D. Xue, X. Yan and L. Wang, Powder Technol. 191, 98 (2009).

16. C. Yan, L. Zou, D. Xue, J. Xu and M. Liu, J. Mater. Sci. 43, 2263 (2008).

17. D. Xue, L. Zou, L. Wang and X. Yan, Modern Phys. Lett. B 23, 3761 (2009).

18. C. Yan, D. Xue, L. Zou, X. Yan and W. Wang, J. Cryst. Growth 282, 448 (2005).

19. K. Chen, G. Li and D. Xue, Funct. Mater. Lett. 9, 1640001 (2016).

20. L. Wang, J. Wang, D. den Engelsen, J. Wu, Y. Du, H. Li and X. Jia, J. Nanoelectron. Optoelectron. 12, 512 (2017).

21. C. Sun, S. Song, D. Xue and H. Zhang, Funct. Mater. Lett. 5, 1230002 (2012).

22. G. Li, K. Chen, J. Jin and D. Xue, Chinese J. Appl. Chem. 34, 71 (2017).

23. K. Chen and D. Xue, Sci. Sin. Technol. 45, 36 (2015).

24. H. Chen, X. Wen, Y. Guan, J. Min, Y. Wen, H. Yang, X. Chen, Y. Li, X. Yang and T. Tang, Fire Mater. 40, 1090 (2016).

25. L. Zong, L. Li, J. Zhang, X. Yang, G. Lu and Z. Tang, J. Cluster Sci. 27, 1831 (2016). 